\title{
A Philosophical Comparison of the Educational Thoughts of Obafemi Awolowo and Tai Solarin
}

\author{
Oladele Abiodun Balogun \\ Department of Philosophy \\ Olabisi Onabanjo University, Nigeria \\ balogundele@yahoo.com
}

\author{
Thought and Practice: A Journal of the Philosophical Association of Kenya (PAK) \\ New Series, Vol.1 No.2, December 2009, pp.61-72 \\ thoughtandpractice@gmail.com OR thoughtandpractice@uonbi.ac.ke
}

\begin{abstract}
This paper compares the educational thoughts of Obafemi Awolowo and Tai Solarin. Its methodology is critical and comparative. The paper argues that the variations of the political philosophies of the two thinkers account for the differences in their views on education. It further contends that the educational ideas of both thinkers reflect African cultural experiences. The paper also explores the possibility of integrating the insights of the two thinkers into the educational policies and practices of contemporary African societies.
\end{abstract}

\section{Introduction}

The educational views of Western thinkers, be they classical, modern or contemporary, have often received celebrated acceptance by African scholars and political leaders. Notably, in West African states, there is the high tempo of following the residual paths of Western educational thinkers such as Plato, Aristotle, Rousseau, Froebel, Pentalloazi, Dewey and Sartre in the quest to formulate and implement sound educational policies. While there is nothing inherently wrong with appropriating educational ideas from non-African cultural backgrounds, what is problematic is that we are so engrossed in this trend that our own models, whatever their worth, are rarely considered. Hardly do we realize that an idea is 
never good in itself; rather, its worth can only be assessed in terms of whether or not it helps in meeting certain needs. We have failed to recognise that just as our problems differ from those of the Occident, so must be our solutions. Furthermore, in our march to educational greatness, we have, like most other nations of the world, been blessed with great thinkers, who have curved a niche for what can be rightly referred to as contemporary African educational thought.

Consequently, this paper explores the African orientation in educational theory. Nevertheless, while there are many notable African educational thinkers, it would not be practical to discuss the whole spectrum of their prescriptions here. The author has therefore selected two Nigerian educational thinkers, with a view to undertaking a comparative appraisal of their reflections, and to deduce therefrom the relevance of their philosophies to educational systems in contemporary Africa.

The paper is organized into five sections. Following this introduction, we discuss the general philosophies of the two thinkers under consideration, and the corresponding educational ideas entertained by each of them in sections two and three respectively. The fourth section is an exercise in comparative analysis of the points of divergence and convergence of Awolowo and Solarin on issues such as the meaning and purpose of education, the nature and structure of the curriculum, the ideal method of teaching, the ideal teacher, and the traits of an educated person. The fifth section, which is the concluding part, articulates the relevance of Awolowo's and Solarin's educational thoughts to contemporary African educational systems.

\section{The Educational Thought of Obafemi A wolowo}

To adequately understand Awolowo's educational thought, it is helpful to set out with a brief outline of his biography and general philosophy. Obafemi Awolowo (1909-1987) was born into an agrarian and peaceful society, IKenne, Ogun State, Nigeria (Awolowo 1982, 6). At the age of eleven, he lost his father. His schooling stopped at this point for a while, and he had to practically begin to fend for himself at that tender age. He later proceeded to Abeokuta to complete his primary school education, which he did in 1926. In order to achieve this, he worked at various times as a houseboy, a water-carrier, and a fire-wood seller. He joined Wesley College, Ibadan, in 1927 for a teacher training course that would have led to the award of a Higher Elementary Teacher's Certificate, but left after spending only a year there 
(Awolowo 1982, 65). He worked as a "Provisional Teacher" in 1928 at the Wesleyan (now Methodist) school, Ogbe, Abeokuta, before returning to Lagos in 1930, where he worked at various times as a typist, newspaper reporter, money lender, trade unionist, and later as a produce buyer.

He proceeded to obtain the B. Comm. Degree of the University of London in $1940 . \mathrm{He}$ qualified for the LL.B. of the University of London, and was called to the English bar the same year. His three years stay in London was, according to him, his most productive years, in which he formed the Egbe Omo Oduduwa (that consequently joined other forces in agitating for Nigeria's independence), and completed writing his first book, Path to Nigerian Freedom (Awolowo 1982, 123). Among his other works are The Voice of Reason, The Voice of Courage, The Problems of Africa: The Need for Ideological Reappraisal, and The Peoples' Republic.

Awolowo was a thinker, ideologue, statesman and political prophet. Being the first Premier of the Western Region in 1954, his sojourn through the rank and file of Nigerian politics is remarkable because of his immense contribution to the Nigerian project. His numerous works remain a testimony to the fecundity of his mind. Awolowo's legacies include his progressive political ideas on fiscal federalism, socialist democracy, ethnic autonomy, fairness and equity in resource allocation, planned development, and liberal and scientific education.

Our conviction is that the general system of a thinker's philosophy influences his/her views on education, having an impact on his/prescriptions on educational goals, the curriculum, teaching method and school structure. Awolowo's general philosophy is based on his metaphysical and socio-political thought. Thoroughly idealistic in character, his metaphysical position is a concern for a harmonious universe and the human being's place in it. His concept of human nature grows out of his understanding of the nature of the universe, so that the kind of society he visualizes is that which will enable the individual human being to play his/her part effectively in maintaining the harmonious state of things. The human being, Awolowo tells us, is dual in nature: he/she has a body and a mind (Awolowo 1981, 12). Nevertheless, Awolowo takes the mental to be superior to the physical. He holds that "the fundamental law is that thought is the cause and the material world only an effect" (Awolowo 1968, 187). Awolowo conceives the human being as a prime mover in every activity - a creative, free and purposively dynamic being in nature. Awolowo believes that the kind of 
individual he conceptualizes can best be moulded under conditions that are democratic and socialistic in nature.

Holding that the human person is a social being by nature, Awolowo supports socialism as an economic system, seeing it as an arrangement that promotes human welfare (Enoch 1996, 81). Democratic socialism is, according to Awolowo (1981), a process of commitment to achieving the political aims of individual well-being through the application of the principles of social justice, equal opportunity and personal freedom for all, and to allowing every individual to lead a full and happy life. It is also an ideological process of achieving national greatness and international brotherhood.

Against the backdrop of his general philosophic outlook, Awolowo provides some of the strongest arguments for universal and free education in Nigeria. For him, education is:

... a systematic course of instruction involving giving intellectual and moral training to persons, bringing up the young, helping the young to develop, to lead out the best in him, and to evolve an integral personality (Awolowo 1981, 12).

Awolowo's conception of education lays emphasis on the three most important aspects of human growth, namely, mental development, spiritual self-realization and physical well being.

As a socialist, Awolowo espouses universal and free education. Basic to socialism are the ideals of justice and equality, which stipulate that natural resources belong to all citizens equally. Consequently, Awolowo canvasses for equal educational opportunities (Awolowo 1970, 35). In order to make education accessible to all, he recommends a system of free education. In this regard, Awolowo rejects the practice of boarding schooling, accusing it of only catering for the few rich. He even rejects giving of loans or bursaries to indigent students as a means of offsetting family economic inequalities, because, for him, such an offer is based on the earlier false presuppositions of an equal chance of being in school by all. He does not even share some of what have become official policies in the Nigerian educational system. For instance, he does not support the quota system of admission into secondary and post-secondary institutions. This is due to his belief that these measures amount to accelerating the educational advancement of some sections of the country at the expense of others, which, in his view, will generate ill feelings like the ones it is attempting to address. 
For Awolowo (1970), the best approach to the problem of the numerically inferior backward areas (like the Northern part of Nigeria), which will not at the same time undermine the development potential of the advantaged sections (such as the Southern states of Nigeria) is free and compulsory primary education. In addition, he endorses, very overwhelmingly, the principles of equal educational outcomes, which simply means the provision of equal opportunities for employment of those with the same level of education and intellectual capabilities.

In defense of his socialist philosophy of free basic education, Awolowo $(1970,40)$ argues that education alone provides an avenue for the equal enjoyment of other human rights. Politically, he believes that the educated individual stands a better chance of playing an active role in the affairs of society than one without education. Education brings about full personality development. To make education a right of everyone, is to Awolowo, a guarantee that the general population will be elevated to the point where other human rights can be demanded and defended. Awolowo predicates the economic well-being of an individual to his/her level of education, and goes on to assert that because economic advantages translate into other forms of inequalities, education can be relied upon to effect some degree of corresponding social equalisation.

A philosophy of education that supports free and compulsory education for the entire citizenry must, at the same time, be concerned with issues of control of the educational system. Awolowo does not advocate a single pattern of control of the nation's educational system, which centralizes the system with the federal government in charge. Rather, he identifies with a centralized, decentralized and dual control pattern of the educational system (Awolowo 1970, 61). This pattern implies that education should be the responsibility of the different levels of government - local, state and federal. The state is to have full control over all the levels of education. Adult education is to be the responsibility of local governments, with the overall coordination provided by the state government. Secondary and teacher education is to be the responsibility of the state government. The state and federal governments are to have concurrent responsibility for the establishment and management of Polytechnics and Universities (Unity Party of Nigeria n.d., No.6). Such responsibility involves among other things financing the system, formulating and executing policies that 
will regulate the system, and putting controls and monitoring mechanisms in place in the running of the system

From the foregoing exposition, it is evident that the major concerns of Awolowo's educational thought are two-fold, namely, the goal of education and the enabling environment through which it can be implemented. The goal, according to Awolowo, is mental magnitude and the means to it is social democracy. Mental magnitude is the position that the mental aspect of man is superior to the physical element of a person and should take control over the emotions, desires, and actions of man. Awolowo defines mental magnitude as freedom from:

(1) negative emotions of anger, hate, fear, envy or jealousy, selfishness or greed;

(2) indulgence in the wrong types of food and drink, and in ostentatious consumption;

(3) excessive or immoral craving for sex (Awolowo 1968, 230).

Mental magnitude is therefore a state of intellectual greatness - a state of conquering what Kant calls "the tyranny of the flesh", thereby becoming free. Awolowo insists that the goal of education should be mental magnitude, and that social democracy is a necessary condition for facilitating the approximation of this ideal.

On the platform of social democracy, Awolowo believes that education with mental magnitude as its goal can lead to the effective training of the mind, the development of the individual's physical and spiritual well-being, and the subjection of appetite to reason (Makinde 2007, 176). In other words, the type of education which aims at achieving mental magnitude emphasizes insight, cognition and the disposition towardsintellectual development over the body. In this regard, the curriculum is designed to favour such disciplines as mathematics, religious studies and other subjects in the humanities.

For Awolowo, then, the effective approach to teaching is the Socratic method, as it gives room for interactive dialogue that enhances human reasoning capacity and the cross fertilization of ideas. The school structure ought to be geared towards the ideals of democratic socialism. As Spring $(1980,41)$ explains, for Awolowo, the goal of education ought to be the development in each individual of the knowledge, interests, ideals, habits and powers that can be used to shape the individual and the society for the better. In other words, education ought to be designed to achieve democratic ideals that uphold the dignity of the human person through the promotion of freedom, equality and human rights. 


\section{The Educational Thought of Tai Solarin}

Tai Solarin (1922-1994) was a renowned Nigerian humanist, social activist and columnist in leading Nigerian Newspapers. He was one of the most prominent educationists in the history of the country, and was at the vanguard of criticism of not only the social, political and economic policies of the nation, but also of the structure and practices of its education system.

A graduate of Manchester and London Universities, he resigned his headship of Molusi College, Ijebu-Igbo, Ogun State, Nigeria, with his wife in 1955 as a result of disagreements over the question of religious practice and instructions predominant in the school. He subsequently established his own school, Mayflower Secondary School, at his home town in Ikenne, Ogun State. He was the principal of the school from 1956 to 1979. He also established the famous Mayflower Junior School in Ikenne (Solarin 1970, 2). Solarin admired communal African societies, because of the absence of sloth in them: every individual had something productive to do for the good of all. According to him, those communalistic societies also discouraged their members from substituting work with prayer. To him, even though they prayed, they were more on their heads than on their knees (Solarin 1959, 37). This may account for Solarin's espousal of secular humanism, which places a high premium on the human being.

In line with secular humanism, Solarin saw no logical relationship between religion and morality. His humanism was existential in character. His passion for the human being rather than for any abstract, transcendental principle or belief in nature as the starting point of all philosophizing is consistent with the existentialist dictum that existence precedes essence. His concern was with the human person as an existential being. Solarin placed emphasis on freedom and choice, and on the need for the human person to uphold the ideal of authentic thinking.

Solarin had an optimistic view of the individual and of society. Both can become anything depending on how they choose, and on whether or not they accept responsibility for their choices. In his view, we are what we choose to become, and can only become what we want to be not through prayer, but through hard work, persistence and courage. There is also a clear pragmatic thrust in Solarin's philosophy - a system of thought which stresses the human 
being's use of intelligence to overcome problems that confront him/her in his/her interactions with the environment (Enoh 1996, 165). The implication of this is that the inculcation of selfreliance through problem-solving skills ought to be central to education. Solarin observes that among Nigerians, the spirit of self-reliance and resourcefulness have given way to indolence, parasitism and the attraction of anything foreign.

Solarin provides a very comprehensive philosophy of education, which is sensitive to both the school and the wider society. He believes that the gateway to societal transformation is the transformation of the school system itself:

It is impossible for a country to change, if the education of that country is not undergoing a change. A change no matter how infinitesimal is only possible with the education of the people (Solarin 1992, 20).

Solarin identifies what to him are the problems confronting the education system in Nigeria. Pertinent among these are parasitism and indolence, emphasis on paper qualifications and enslavement of the mind. Accordingly, education should aim to inculcate in individuals the habit of work, and to equip them with the necessary skills that will enable them to contribute their quota to the growth of the society rather than remain huge parasites. Education should therefore be more of the development of problem-solving skills with which to confront the various challenges of life, rather than the acquisition of information that will never be put to productive use.

Solarin avers further that the colonial education bequeathed to Africans did not awaken their critical consciousness. Rather than free an individual's mental powers, this education promotes fear of almost everything - parents, teachers, day-light, darkness, thinking and speaking (Solarin 1992, 20). Solarin primarily attributes this mental enslavement to the veil of religion, which allegedly preaches fatalism and renders the individual irrelevant even to himself/herself. Consequently, for Solarin, the goal of education should be the building of a new community by producing individuals who can stand on their feet, men and women who are mentally free and independent (Solarin 1963, 5).

The second aim of education for Solarin is mental freedom. In his opinion, an educated person is essentially one who is autonomous, reflective, critical, and capable of making choices without undue external influence. To him, a curriculum is only relevant if it grows out of the peculiar circumstances of the living environment in which the school is situated, 
and in so far as it helps the individual to understand that environment. The school system is therefore society simplified. Thus for Solarin, the curriculum should be made relevant to local needs. Solarin outlines a very detailed curriculum plan for the primary school level based on the principles of validity, relevance to life, variety, suitability and cumulativeness. At the secondary school level, he insists that all students study science and acquire vocational skills (Solarin 1970, 94). Solarin believes that the humanities (religion excluded) should be taught at this level, so as to bring about a broad understanding of the human being on the one hand, and on the other hand, to create a balance between such knowledge and practical disposition towards the betterment of the society. A very low place is accorded to sports in Solarin's curriculum proposal.

Solarin believes that at the tertiary level, the curriculum should be extensive in order to cater for the varied interests of the learners. He recommends a general curriculum during the first year, with specialization in the later years. Whether in history, geography, science or music, it is his belief that what is included in the curriculum must be relevant to life. On the whole, Solarin's curriculum is characterized by relevance, suitability to the learners' level of attainment, balance between practical and academic studies, a common practical scheme for all in order to avoid parasitism by some, highly informal character, teaching through practice rather than theory, and relating subject matter to the present (Enoh 2001, 201).

What is more, Solarin recommends a method of group learning through research in order for students to discover facts on their own. He also advocates a democratic conception of education, where there is a free dialogue between the teachers and students, between the school management and the students union, and between the school and the local communities. It is in full recognition of this democratic concept of education that Solarin advocates the boarding school system. According to him, "it is the best welder of the various peoples in a country into an indivisible mould" (Solarin 1990, 79). Also significant in Solarin's thought are his remarks on equal educational opportunities. Denouncing all forms of discrimination, he avers that all Nigerians have equal rights to education, so that obstacles such as social status, gender and religion should not be erected in the way of equal access to it (Solarin 1963, 10). 


\section{Divergence and Convergence in Obafemi Awolowo's and Tai Solarin's educational thoughts}

Both Awolowo and Solarin were deeply concerned about the unsatisfactory state of education in their country, and offered prescriptions on how best to address it. However, while the historical periods in which the two scholars write are the same, they differ in their approaches. Whereas Awolowo's educational philosophy can be aptly described as socialistidealist, that of Tai Solarin is existential-pragmatic. The historical circumstance behind Awolowo's philosophy of education was political. Consequently, there is a degree of harmony between his general socio-political idea, namely, democratic socialism, and his philosophy of education, with the latter being primarily aimed at achieving the goals of the former. On the other hand, for Solarin, the historical circumstances surrounding his educational writing has much to do with the aftermath of the colonial experience of Nigeria in the realm of education, and his passion for making his philosophy of secular humanism relevant to education (Okanlawon and Fasanmi 2000, 12).

Furthermore, the thoughts of Awolowo and Solarin both reflect African cultural and political realities and experiences. For example, influenced by the potentially explosive nature of the educational disparity between the Northern and Southern states of Nigeria, the two thinkers were in agreement on the need for equality of educational opportunity. Nevertheless, Solarin did not give a concrete outline of how the quest for equality of educational opportunity could translate into reality. This lacuna is attributable to the fact that unlike Awolowo, Solarin was not a professional politician. For Awolowo, the quest for equality is in consonance with the principles of democratic socialism, and under the welfare state, equality to educational opportunity could be realized through compulsory free basic education for all the citizenry.

Moreover, the existential-pragmatic inclination of Solarin probably accounts for his endorsement of such educational values as the sense of personal responsibility, independence of thought, and creative and problem-solving capacities. Unlike him however, Awolowo's educational thought is more disposed towards mental development over the body. What is more, while religion plays a crucial role in the latter's prescriptions, secular humanism is dominant in the former's. In addition, Awolowo and Solarin are both advocates of democratic education, but they interpret the models of boarding schools and unity schools differently. Awolowo rejects boarding schools on the ground that they perpetuate inequality in education; 
he also jettisons unity schools on the basis that the quota system used in them allows for social injustice. However, for Solarin both boarding schools and unity schools are democratic forces for molding people from different parts of the country into a single, indivisible Nigerian nation. Besides, due to the variation in their general philosophies, Awolowo's and Solarin's thoughts on some key aspects of education differ considerably, as is evident with regard to their views on the content of the curriculum and the appropriate teaching methodology. For instance, whereas Awolowo prescribes the Socratic method of teaching, Solarin recommends an activity-based and learner-centered approach.

\section{Conclusion}

The tendency has persisted in African Academia of denying or neglecting the relevance of the thoughts of African thinkers to contemporary African educational systems. In an attempt to contribute towards remedying this sorry situation, this paper has undertaken a critical comparison of the educational thoughts of Obafemi Awolowo and Tai Solarin. In the light of the preceding discussion, it is our considered view that a synthetic application of Solarin's existential-pragmatism and Awolowo's socialist-idealism in contemporary Africa would make the continent's education systems both appropriately conservative and transformative (see Obanya 2004). The existential-pragmatic basis of Solarin's philosophy of education is transformative in essence, because it has the potential to open African societies to the wider horizon of science and technology. On its part, Awolowo's Socialist-idealist educational philosophy has the capacity to inculcate into pupils the intellectual, moral and democratic values prerequisite for good citizenship. In addition, if the ideas of these two thinkers on equality of educational opportunity were to be implemented in Africa, education would truly become a catalyst for development in the continent, as the majority of her people would be adequately equipped to participate in the positive transformation of their societies. Thus it is our view that many of the problems in Africa's education systems would dissolve if the educational thoughts of Awolowo and Solarin were employed to address them.

\section{References}

Awolowo, Obafemi. 1981. Voice of Wisdom. Akure: Fagbamigbe Publishers. --. 1982. My Early Life. Ikeja: John West Publications.

--. 1970. The Strategy and Tactics of the People's Republic of Nigeria. Ibadan: Macmillan Nigeria Publishers Ltd.

--. 1968. The People's Republic. Ibadan: Oxford University Press.

Enoh, A.O. 1996. Main Currents in Nigerian Educational Thoughts. Jos: Midland Press. 
--. 2001. "Tai Solarin Curricular Beliefs and the Ghost of John Dewey". Journal of the Institute of Education, Vol.2 pp.198-205.

Makinde, M. A. 2007. African Philosophy: The Demise of a Controversy. Ile-Ife: Obafemi Awolowo University Press Limited.

Obanya, P. 2004. The Dilemma of Education in Africa. Ibadan: Heinemann Educational Books.

Okanlawon, A.B. and Taiwo Fasanmi eds. 2000. Tai Solarin: The making of a Humanist. Ikeja: Admass Publishing Co.

Solarin, Tai. 1959. Towards Nigeria's Moral Self-Government. Ibadan: Ibadan University Press.

--. 1963. Our Grammar School must go. Ibadan: Ibadan University Press.

--. 1970. Mayflower: The Story of a School. Ikeja: John West Publications.

--. 1992. Conscience of the Nation: Profound Thoughts of Dr. Tai Solarin. Compiled by Yomi Mamora. Ibadan: Famload Books.

--. 1990. "National Educational Policy and Boarding Schools in Developing Countries: The Rural Aspect". All Nigeria Conference of Principals Journal, Vol.5, pp.70-80.

Spring, Joel. 1980. Educating the Worker Citizen: the Social, Economic, and Political Foundations of Education. New York: Longman.

Unity Party of Nigeria. n.d. Policy Papers. Lagos: Etso Printers. 